\title{
Improved Indonesian Language Learning Outcomes Material Intrinsic Elements of Stories through Video Media for Class IV Students
}

\section{Septi Dwi Harmini}

\author{
SD Negeri 1 Tirip \\ septidwiharmini83@gmail.com
}

\section{Article History}

accepted 14/11/2020

approved 21/11/2020

published 26/11/2020

\begin{abstract}
The purpose of this study was to improve the learning outcomes of students in the Indonesian muple material of the intrinsic elements of stories in grade IV elementary schools through audiovisual media in the form of video media. The research conducted was a three-cycle Classroom Action Research (CAR). The stages of each cycle are planning, implementing, observing and reflecting. Each cycle a post test is held to determine the development of students. The initial condition before the action was carried out, the data obtained from the students who had completed was $36.8 \%$. In the first cycle, students who completed after carrying out the post test were $52.6 \%$. In the second cycle students who completed after carrying out the post test were 84.2\%. In the third cycle students who completed after carrying out the post test were $94.7 \%$. These results indicate that video media can improve student learning outcomes, especially Indonesian muple material, the intrinsic elements of stories at SD Negeri 1 Tirip
\end{abstract}

Keywords: Learning outcomes, Videos, Indonesian

\begin{abstract}
Abstrak
Tujuan penelitian ini adalah untuk meningkatkan hasil belajar peserta didik pada mupel Bahasa Indonesia materi unsur-unsur intrinsik cerita di sekolah dasar kelas IV melalui media audiovisual berupa media video. Penelitian yang dilakukan adalah Penelitian Tindakan Kelas (PTK) tiga siklus. Tahapan setiap siklusnya adalah perencanaan, pelaksanaan, observasi dan refleksi. Setiap siklus diadakan post test untuk mengetahui perkembangan peserta didik. Kondisi awal sebelum diadakan tindakan diperoleh data peserta didik yang tuntas sebesar $36,8 \%$. Pada siklus I peserta didik yang tuntas setelah melaksanakan post test sebesar $52,6 \%$. Pada siklus II peserta didik yang tuntas setelah melaksanakan post test $84,2 \%$. Pada siklus III peserta didik yang tuntas setelah melaksanakan post test sebesar $94,7 \%$. Hasil ini menunjukkan bahwa media video dapat meningkatkan hasil belajar peserta didik khususnya mupel Bahasa Indonesia materi unsur-unsur intrinsik cerita di SD Negeri 1 Tirip.
\end{abstract}

Kata kunci: Hasil belajar, Video, Bahasa Indonesia

Social, Humanities, and Education Studies (SHEs): Conference Series https://jurnal.uns.ac.id/shes

p-ISSN 2620-9284

e-ISSN 2620-9292 


\section{PENDAHULUAN}

Wabah corona virus disease 2019 (Covid-19) yang telah melanda 215 negara di dunia, memberikan tantangan tersendiri bagi lembaga pendidikan, khususnya Perguruan Tinggi. Untuk melawan Covid-19 Pemerintah telah melarang untuk berkerumun, pembatasan sosial (social distancing) dan menjaga jarak fisik (physical distancing), memakai masker dan selalu cuci tangan menggunakan sabun dengan air mengalir. Melalui Kementerian Pendidikan dan Kebudayaan Pemerintah telah melarang sekolah dasar untuk melaksanakan pembelajaran tatap muka (konvensional) dan memerintahkan untuk menyelenggarakan pembelajaran secara daring (Surat Edaran Kemendikbud Dikti No. 1 tahun 2020). Sekolah dasar dituntun untuk dapat menyelenggarakan pembelajaran secara daring atau on line (Firman, F., \& Rahayu, S., 2020).

Pembelajaran secara daring telah menjadi tuntutan dunia pendidikan sejak beberapa tahun terakhir. Seiring dengan kemajuan perkembangan informasi teknologi, globalisasi pun menjadi semakin pesat. Menurut (Prasojo \& Riyanto, 2011) teknologi informasi diartikan sebagai ilmu pengetahuan dalam bidang informasi yang berbasis komputer dan perkembangannya sangat pesat. Menurut (Setyosari \& Punaji, 2015) meyatakan bahwa pembelajaran melalui jaringan memiliki potensi-potensi, antara lain: kebermaknaan belajar, kemudahan mengakses dan peningkatan hasil belajar. Dalam konteks belajar secara online, peserta didik dapat berhubungan secara cepat dan langsung dengan teks, gambar, suara, data pengajar. Tutorial tatap muka diganti dengan perantara teknologi yang disebut tuweb diharapkan hasil belajar peserta didik menjadi bagus di tengah maraknya virus Covid-19. Untuk itu dengan tuweb/bantuan teknologi yang mengikuti proses tutorial akan menghasilkan prestasi peserta didik yang meningkat karena tidak hanya penguasaan materi melainkan juga menguasai teknologinya.

Menurut Brunner dalam Sugandi (2007:36) ada empat hal pokok penting yang perlu diperhatikan yaitu peranan pengalaman struktur pengetahuan, kesiapan mempelajari sesuatu, intuisi dan cara membangkitkan motivasi belajar. Guru dituntut untuk bisa membawa peserta didik ke dalam dunia yang menyenangkan di dalam pembelajaran. Peserta didik yang merasa nyaman dan senang, maka akan berani untuk aktif dan akan mempunyai motivasi lebih untuk terus belajar. Peserta didik yang motivasi belajarnya lebih juga biasanya akan mendapatkan hasil belajar yang baik. Guru sebagai pemegang proses pembelajaran harus bisa menyajikan hal terbaik. Pemilihan media pembelajaran yang tepat akan mendukung hasil dari tujuan pembelajaran yang akan dicapai.

Salah satu muatan yang pelajaran yang menuntut penggunaan media pembelajaran yang sesuai adalah muatan pelajaran Bahasa Indonesia. Berdasarkan data yang diperoleh bahwa hasil belajar muatan pelajaran Bahasa Indonesia kelas IV SD Negeri 1 Tirip masih rendah atau di bawah KKM, yaitu 75. Dari total peserta didik di kelas IV sebanyak 19 anak dengan KKM 75, ada 12 peserta didik yang mendapat nilai di bawah KKM dan 7 peserta didik yang mencapai nilai KKM. Itu berarti ada 63,2\% peserta didik yang belum mencapai KKM dan 36,8\% peserta didik yang sudah mencapai KKM. Peserta didik merasa kesulitan dalam memahami pembelajaran.

Menurut Sudjana (2005:3) hasil belajar adalah perubahan tingkah laku siswa setelah melalui proses pembelajaran. Semua perubahan dari proses belajar merupakan suatu hasil belajar dan mengakibatkan manusia berubah dalam sikap dan tingkah lakunya. Menurut Susanto (2013:5) makna hasil belajar yaitu perubahanperubahan yang terjadi pada diri siswa, baik yang menyangkut aspek kognitif, afektif, dan psikomotor sebagai hasil dari kegiatan belajar. Hasil belajar ditegaskan oleh Nawawi dalam K. Brahim (2007:39) (dalam Susanto 2013:5) secara sederhana, yang dimaksud hasil belajar siswa adalah kemampuan yang diperoleh anak setelah melalui kegiatan belajar. Karena belajar itu sendiri merupakan suatu proses dari seseorang 
yang berusaha untuk memperoleh suatu bentuk perubahan perilaku yang relatif menetap. Hasil belajar menurut Dimyati (dalam Ranti, 2007:12) adalah hasil proses belajar dimana pelaku aktif dalam belajar adalah siswa dan pelaku aktif dalam pembelajaran adalah guru. Dari beberapa pendapat tersebut dapat disimpulkan hasil belajar adalah suatu hasil yang dicapai oleh peserta didik sebagai hasil belajar yang diterima setelah melalui proses belajar yang dinyatakan dalam skor yang diperoleh dari hasil tes mengenai sejumlah pelajaran tersebut.

Penggunaan media yang tepat dalam pembelajaran merupakan salah satu upaya untuk memotivasi peserta didik agar dapat meningkatkan hasil belajarnya. Media belajar juga dapat mempermudah peserta didik dalam memahami materi yang disampaikan oleh guru. Dalam hal ini, media audio-visual berupa video lebih konkret digunakan dalam pembelajaran daripada hanya berupa kata-kata dan tulisan saja.

Menurut Dwyer, video mampu merebut 94\% saluran masuknya pesan atau informasi kedalam jiwa manusia melalui mata dan telinga serta mampu untuk membuat orang pada umumnya mengingat $50 \%$ dari apa yang mereka lihat dan dengar dari tayangan program. Pesan yang disampaikan melalui media video dapat mempengaruhi emosi yang kuat dan juga dapat mencapai hasil cepat yang tidak dimiliki oleh media lain.

Menurut Cheppy Riyana (2007) media video pembelajaran adalah media yang menyajikan audio dan visual yang berisi pesan-pesan pembelajaran baik yang berisi konsep, prinsip, prosedur, teori aplikasi pengetahuan untuk membantu pemahaman terhadap suatu materi pembelajaran. Video merupakan bahan pembelajaran tampak dengar (audio visual) yang dapat digunakan untuk menyampaikan pesan-pesan/materi pelajaran. Dikatakan tampak dengar kerena unsur dengar (audio) dan unsur visual/video (tampak) dapat disajikan serentak.

\section{METODE}

Penelitian ini adalah penelitian tindakan kelas dengan menggunakan media audio-visual berupa video. Menurut Kurt Lewin dalam Kunandar (2011:42) penelitian tindakan kelas ini terdiri dari empat tahapan dasar yaitu perencanaan (planning), pelaksanaan (action), pengamatan (observing) dan refleksi (reflecting). Analisis penelitian ini adalah analisis kualitatif model interaktif dimana dalam penelitian ini melakukan analisis awal dari data yang diperoleh, mengembangkan dalam bentuk sajian data, melakukan analisis data di kelas, melakukan verifikasi, merumuskan kesimpulan akhir sebagai temuan penelitian dan merumuskan implikasi kebijakan sebagai bagian dari pengembangan saran dalam laporan akhir penelitian. Penelitian ini dilaksanakan pada peserta didik kelas IV SD Negeri 1 Tirip tahun pelajaran 2020/2021 selama tiga siklus secara daring melalui aplikasi WhatsApp dan Zoom Meeting. Siklus I dilaksanakan pada tanggal 2 November 2020. Siklus II dilaksanakan pada tanggal 9 November 2020. Siklus III dilaksanakan pada tanggal 20 November 2020. Teknik pengumpulan data yang dilakukan dengan observasi dan tes. Observasi dilaksanakan selama proses pembelajaran. Untuk hasil belajar menggunakan tes melaui Google Form.

\section{HASIL DAN PEMBAHASAN}

Pada siklus I pembelajaran dilaksanakan satu kali pertemuan dan untuk mengetahui perkembangan peserta didik selama pembelajaran diadakan tes akhir. Pada siklus I membahas materi unsur-unsur intrinsik cerita dengan mengamati video, tanya jawab, dan diskusi. Berikut ini adalah hasil belajar peserta didik pada siklus I yang dapat dilihat pada tabel berikut. 
SHEs: Conference Series 3 (3) (2020) 831- 837

Tabel 1. Frekuensi Hasil Belajar Peserta Didik Siklus I

\begin{tabular}{ccccc}
\hline No & Nilai & Frekuensi & Scor & Persentase \\
\hline 1 & 43 & 1 & 43 & 5,3 \\
2 & 47 & 1 & 47 & 5,3 \\
3 & 50 & 1 & 50 & 5,3 \\
4 & 53 & 1 & 53 & 5,3 \\
5 & 57 & 1 & 57 & 5,3 \\
6 & 63 & 2 & 126 & 10,5 \\
7 & 67 & 1 & 67 & 5,3 \\
8 & 73 & 1 & 73 & 5,3 \\
9 & 77 & 3 & 231 & 15,8 \\
10 & 83 & 2 & 166 & 10,5 \\
11 & 87 & 3 & 261 & 15,8 \\
12 & 93 & 1 & 93 & 5,3 \\
13 & 97 & 1 & 97 & 5,3 \\
Jumlah & & 19 & 1364 & 100 \\
Rata-rata & & & 72 & \\
Nilai Tertinggi & & 97 & \\
Nilai Terendah & & 47 & \\
Ketuntasan & & & $52,6 \%$ & \\
\hline
\end{tabular}

Dari tabel frekuensi hasil belajar peserta didik pada siklus I di atas, peserta didik yang mendapatkan nilai 43 ada 1 anak (5,3\%), 47 ada 1 anak (5,3\%), 50 ada 1 anak (5,3\%), 53 ada 1 anak (5,3\%), 57 ada 1 anak (5,3\%), 63 ada 2 siswa (10,5\%), 67 ada 1 anak (5,3\%), 73 ada 1 anak (5,3\%), 77 ada 3 anak (15,8\%), 83 ada 2 anak (10,5\%), 87 ada 3 anak (15,8\%), 93 ada 1 anak (5,3\%), dan 97 ada 1 anak (5,3\%).

Berdasarkan data yang diperoleh, hasil analisis dan observasi menunjukkan masih ada 9 siswa yang mendapatkan nilai di bawah KKM (75) sehingga masih ada 9 peserta didik yang belum termotivasi untuk mengikuti pembelajaran. Dengan demikian belum sesuai dengan indikator penelitian (85\%) karena baru mencapai $(52,6 \%)$ peserta didik yang telah tuntas. Peserta didik belum sepenuhnya menguasai materi pembelajaran yang diajarkan walaupun sudah ada peningkatan hasil belajar pada siklus I dari kondisi awal/pra siklus sebesar 15,8\%, untuk itu diputuskan melanjutkan ke siklus II.

Dari hasil refleksi siklus I maka penelitian dilanjutkan ke siklus II. Pada siklus II pembelajaran membahas unsur-unsur intrinsik cerita yang berbeda dengan siklus I dengan mengamati video yang berbeda dari siklus I. Berikut adalah hasil belajar peserta didik pada siklus II yang dapat dilihat pada tabel berikut. 
SHEs: Conference Series 3 (3) (2020) 831- 837

Tabel 2. Frekuensi Hasil Belajar Peserta Didik Siklus II

\begin{tabular}{ccccc}
\hline No & Nilai & Frekuensi & Scor & Persentase \\
\hline 1 & 63 & 1 & 63 & 5,3 \\
2 & 67 & 2 & 134 & 10,5 \\
3 & 77 & 4 & 308 & 21,1 \\
4 & 83 & 3 & 249 & 15,8 \\
5 & 87 & 2 & 174 & 10,5 \\
6 & 90 & 1 & 90 & 5,3 \\
7 & 93 & 1 & 93 & 5,3 \\
8 & 97 & 4 & 388 & 21,1 \\
9 & 100 & 1 & 100 & 5,3 \\
Jumlah & & 19 & 1599 & 100 \\
Rata-rata & & 84 & \\
Nilai Tertinggi & & 100 & \\
Nilai Terendah & & 63 & \\
Ketuntasan & & & $84,2 \%$ & \\
\hline
\end{tabular}

Dari tabel frekuensi hasil belajar peserta didik pada siklus II di atas, peserta didik yang mendapatkan nilai 63 ada 1 anak (5,3\%), 67 ada 2 anak (10,5\%), 77 ada 4 anak (21,1\%), 83 ada 3 siswa (15,8\%), 87 ada 2 siswa (10,5\%), 90 ada 1 siswa (10,5\%), 93 ada 1 anak (5,3\%), 97 ada 4 anak (21,1\%), dan 100 ada 1 anak (5,3\%). Berdasarkan observasi dan analisis data pembelajaran pada siklus II dapat diketahui bahwa peserta didik sudah lebih aktif dalam mengikuti pembelajaran. Sebagian besar peserta didik sudah menguasai materi pembelajaran. Berdasarkan data yang diperoleh, menunjukkan bahwa 16 anak $(84,2 \%)$ telah tuntas di atas nilai KKM (75) dan 3 anak (15,8\%) masih di bawah KKM (75).

Setelah melakukan refleksi pada siklus II, maka diputuskan melanjutkan pada siklus III. Hal ini dilakukan untuk mengetahui sejauh mana peningkatan hasil belajar peserta didik melalui media video. Selain itu juga untuk mempertahankan hasil belajar peserta didik. Dalam pembelajaran siklus III membahas unsur-unsur intrinsik cerita yang berbeda dari siklus I dan II melalui video dan teks cerita. Hasil belajar peserta didik dapat dilihat pada tabel berikut. 
Tabel 3. Frekuensi Hasil Belajar Peserta Didik Siklus III

\begin{tabular}{ccccc}
\hline No & Nilai & Frekuensi & Scor & Persentase \\
\hline 1 & 67 & 1 & 67 & 5,3 \\
2 & 77 & 3 & 231 & 15,8 \\
3 & 83 & 3 & 249 & 15,8 \\
4 & 87 & 2 & 174 & 10,5 \\
5 & 90 & 2 & 180 & 10,5 \\
6 & 93 & 3 & 279 & 15,8 \\
7 & 97 & 4 & 388 & 21,1 \\
8 & 100 & 1 & 100 & 5,3 \\
Jumlah & & 19 & 1668 & 100 \\
Rata-rata & & 88 & \\
Nilai Tertinggi & & 100 & \\
Nilai Terendah & & 67 & \\
Ketuntasan & & & $94,7 \%$ & \\
\hline
\end{tabular}

Berdasarkan data peserta didik yang mendapatkan nilai 67 ada 1 anak $(5,3 \%)$, 77 ada 3 anak (15,8\%), 83 ada 3 anak (15,8\%), 87 ada 2 anak (10,5\%), 90 ada 2 siswa (10,5\%), 93 ada 3 siswa (15,8\%), 97 ada 4 siswa (21,1\%), dan 100 ada 1 anak $(5,3 \%)$.

Nilai terendah pada siklus III adalah 67, pada siklus II 63 berarti mengalami peningkatan sebanyak 4 poin. Nilai rata-rata kelas juga mengalami peningkatan dari 84 pada siklus II menjadi 88 pada siklus III atau naik 4 poin. Hal ini menunjukkan bahwa hasil belajar peserta didik mengalami peningkatan dari setiap siklus ke siklus berikutnya.

Peningkatan hasil belajar peserta didik dalam setiap siklusnya dapat dilihat pada tabel berikut.

Tabel 4. Peningkatan Ketuntasan Hasil Belajar Peserta Didik

\begin{tabular}{cccccccccc}
\hline \multirow{2}{*}{ No } & \multirow{2}{*}{ Ketuntasan } & \multicolumn{2}{c}{ Pra Siklus } & \multicolumn{2}{c}{ Siklus I } & \multicolumn{3}{c}{ Siklus II } & \multicolumn{2}{c}{ Siklus III } \\
& & Jml & $\%$ & Jml & $\%$ & Jml & $\%$ & Jml & $\%$ \\
\cline { 2 - 10 } 1 & TelahTuntas & 7 & 36,8 & 10 & 52,6 & 16 & 84,2 & 18 & 94,7 \\
2 & Belum Tuntas & 12 & 63,2 & 9 & 47,4 & 3 & 15,8 & 1 & 5,3 \\
\hline
\end{tabular}

Dengan melihat data di atas dapat diuraikan bahwa pada pra siklus perta didik yang tuntas hanya 7 anak dari 19 anak $(36,8 \%)$, pada siklus I peserta didik yang tuntas 10 anak dari 19 anak (52,6\%), pada siklus II pesrta didik yang tuntas 16 anak dari 19 anak (84,2\%), dan pada Siklus III peserta didik yang tuntas 18 anak dari 19 anak (94,7\%). Sedangkan peserta didik yang belum tuntas pada pra siklus, 12 anak dari 19 anak belum tuntas $(63,2 \%)$, pada siklus I, 9 anak dari 19 anak belum tuntas $(47,4 \%)$, pada siklus II, 3 anak dari 19 anak belum tuntas (15,8\%), dan pada siklus III, 1 anak dari 19 anak yang belum tuntas $(5,3 \%)$.

Dari tiga siklus yang sudah dilaksanakan dapat dipastikan bahwa media video dapat meningkatkan hasil belajar peserta didik pada mupel Bahasa Indonesia di kelas IV SD Negeri 1 Tirip. Hal ini sesuai dengan pendapat Dwyer, video mampu merebut 
94\% saluran masuknya pesan atau informasi kedalam jiwa manusia melalui mata dan telinga serta mampu untuk membuat orang pada umumnya mengingat $50 \%$ dari apa yang mereka lihat dan dengar dari tayangan program. Pesan yang disampaikan melalui media video dapat mempengaruhi emosi yang kuat dan juga dapat mencapai hasil cepat yang tidak dimiliki oleh media lain.

\section{SIMPULAN}

Pemanfaatan media audio-visual berupa video dapat meningkatkan hasil belajar peserta didik kelas IV mupel Bahasa Indonesia materi unsur-unsur intrinsik cerita. Peningkatan yang terjadi karena adanya kesan yang mendalam dari peserta didik terhadap materi yang diajarkan melalui video yang ditayangkan. Peserta didik merasa senang dalam mengikuti pembelajaran sehingga mereka akan mudah mengingat materi yang disampaikan. Berdasarkan penelitian yang telah dilaksanakan salah satu media yang dapat digunakan oleh guru adalah video karena media ini sangat cocok digunakan dalam keadaan pandemi seperti ini, apalagi dalam kondisi belajar dari rumah. Peserta didik dapat membangun pengetahuannya sendiri melalui video yang diberikan. Guru juga dapat bekerja sama dengan orang tua untuk memantau selama proses pembelajaran.

\section{DAFTAR PUSTAKA}

Ahmad Susanto. (2013). Teori Belajar dan Pembelajaran di Sekolah Dasar. Jakarta: Kencana Prenadamedia Group

Cheppy Riyana. (2007). Pedoman Pengembangan Media Video. Bandung: Program P3Al Universitas Pendidikan Indonesia

Dimyati dalam Ranti 2007:12 dalam http:/one.indoskripsi.com

Kunandar. 2011. Langkah Mudah Penelitian Tindakan Kelas sebagai Pengembang Profesi Guru. Jakarta: PT Raja Grafindo Persada

Pembelajaran Daring di Tengah Wabah Covid-19 (Online Learning in the Middle of the Covid-19 Pandemic) Ali Sadikin*, Afreni Hamidah Halaman 215

Prasojo, Riyanto. 2011. Teknologi Informasi Pendidikan. Yoyakarta: Gava Media

Sugandi, A.2007. Teori Pembelajaran. Semarang: UNNES Press. 